\title{
MLADI, DOMOLJUBJE IN NACIONALNA VARNOST: VOJSKA KOT STEBER DOMOLJUBNIH STRUKTUR
}

\author{
THE YOUNG, PATRIOTISM AND NATIONAL \\ SECURITY: ARMED FORCES AS A PILLAR \\ OF PATRIOTIC STRUCTURES
}

Povzetek Globalizacija je bistveno spremenila mednarodno varnostno arhitekturo. Globoke reforme nacionalnovarnostnih sistemov, ki se osredotočajo predvsem na vedno višjo profesionalizacijo in specializacijo, so postale nujna posledica. Pa vendar je, če želimo zagotoviti neko stopnjo varnosti, pogoj nedvomno osebni motiv oziroma motivacija posameznika tako pred vstopom kakor pri opravljanju nalog znotraj nacionalnovarnostnega sistema. Motivacija pa bolj kot kjer koli drugod izhaja iz občutka domoljubja pri posamezniku, zato države domoljubju v sodobnih nacionalnovarnostnih sistemih namenjajo veliko pozornosti. Vprašanje je, ali se tako vedenje preslikava $\mathrm{v}$ civilno družbo, katere pomemben del je nacionalnovarnostni sistem. Še posebno zanimivo je ugotavljati povezavo med mladimi in domoljubjem ter nacionalno varnostjo, saj je tudi od tega odnosa odvisna prihodnost nacionalnovarnostnega sistema kot tudi prihodnjega zagotavljanja varnosti. Rezultati kažejo zaskrbljujoč odnos mladih do vprašanj vojske in vojaških zadev ter politike in političnih zadev.

Ključne besede

\section{Domoljubje, nacionalna varnost, vojska, identiteta, nacionalizem.}

Abstract Globalization has significantly changed the international security architecture. Radical reforms of national security systems have become a necessary consequence, focusing mainly on the higher level of professionalization and specialization. However, in order to ensure a certain level of security, the pre-condition undoubtedly lies in the personal motive or motivation of individuals both, before they join the military service and when they perform duties within the national security system. Motivation, more than anything else, derives from an individual's sense of patriotism. Therefore, individual countries devote a lot of attention to patriotism in modern national-security systems. At this point the question arises whether such behaviour is reflected also in the civil society, whose important part is the national security 
system. It is particularly interesting to determine a connection between the youth, patriotism and national security, as this relationship is important for the future of both, the national security system and provision of security.

\section{Key words Patriotism, national security, armed forces, identity, nationalism.}

Uvod Domoljubje ali patriotizem je čustvo, je fenomen, ki se razvije samoniklo, saj se vsak posameznik rodi v nekem socialno-kulturnem okolju. To ga v nekem obsegu določa, zato domoljubja ni mogoče kupiti, ukazati ali prepovedati. Zaradi teh značilnosti moramo domoljubje razumeti kot čustvo, ki ima v hierarhiji vrednot zato poseben položaj. Ljubiti dom in domovino v širšem kontekstu je nekaj, kar je in bo za vedno žlahtno dejanje, saj pomaga in zagotavlja preživetje tako družine kot posledično naroda ali nacije. Temeljna hipoteza, ki utemeljuje ta članek, se glasi, da so oborožene sile eden izmed temeljev domoljubja in da vojska deluje in mora delovati kot pomemben steber domoljubnih vzorcev, kar naj bi se kazalo v civilni družbi ter na populaciji mladih.

Široko sprejeto razumevanje pojmuje domoljubje kot »občutek pripadnosti narodu« (Conover in Feldman, 1987, str. 1) ali »stopnja ljubezni in ponosa do določenega naroda « (Kosterman in Feshbach, 1989, str. 271). Višjo stopnjo nesoglasja pa je mogoče zaslediti glede tega, kako se domoljubje meri. Pogosto se domoljubni elementi povezujejo s politično ideologijo. Tako predvsem v ZDA velja aksiom, da politični konservativci delujejo bolj domoljubno kot liberalci. Prav tako je mogoče v ZDA identificirati tri različne prevladujoče vrste domoljubja (Schatz in Stauc, 1997; Parker, 2003). Prvo je simbolno domoljubje, ki temelji na čustveni navezanosti na simbole ameriške države in ZDA. Drugo je konstruktivno domoljubje, ki predstavlja racionalno razsežnost tega pojava, ki se izraža skozi konstruktivno kritiko vlade in njenega početja. Tretja vrsta pa je slepo domoljubje, katerega gonilna sila v ozadju je iracionalna razsežnost, ki v osnovi predstavlja »ekstremno zvestobo, ki ne sme biti postavljena pod vprašaj« (Parker, 2003, str. 14).

Tocqueville govori o nagonski ljubezni do lastne države, kar pomeni, da je zanj domoljubje nekaj povsem naravnega. Gre torej za naravno željo po teritorialnosti, ki skupaj z družino predstavlja primarno vez posameznikove osebnosti s teritorialno skupnostjo, ki jo je nezavedno ponotranjil. Ljudje tako postanejo predani ljudem in krajem, ki so jim znani, ter vzgoji, ki so je bili deležni in jim predstavlja korenine domoljubja. Ne nazadnje ne smemo pozabiti dejstva, da vse to poteka v danih socialnokulturnih, zgodovinsko regionalnih in drugih okoliščinah, na katere posameznik ne more vplivati. Človeku so z rojstvom dani neka kultura in vedenjski vzorci, ki so značilni za vse pripadnike nekega naroda in se močno kažejo v nadaljnjem življenju človeka. Domoljubna čustva in občutki se tako kažejo v prvobitni navezanosti na neko ozemlje in družbo. Domoljubje najdemo tudi na seznamu državljanskih vrlin, in sicer kot izpeljano vrlino, ki je odvisna od kraja in časa in ne od splošne moralne značilnosti človeka. 
Izražanje domoljubja postane še bistveno bolj pomembno pri vprašanju aktivnosti oziroma pasivnosti posameznika kot opredeljevanje ali karakteriziranje domoljubja skladno z že predstavljeno tipologijo domoljubja. Kahne in Middaugh (2006, str. 603) menita, da so aktivni domoljubi pomemben element in celo temelj sodobnih demokracij, saj s svojo aktivnostjo izkazujejo politično participacijo ter tako sooblikujejo državo, v kateri živijo. Z drugimi besedami, svojih stališč ne ohranijo zase, temveč z različnimi aktivnostmi, tudi udejanjanjem pasivne in aktivne politične pravice, tvorno prispevajo k oblikovanju domoljubja. Na podlagi teh dejstev je mogoče celo trditi, da so tako aktivni člani neke skupnosti evolutivni tvorci domoljubja.

V primeru različnih izrednih razmer, ki pomenijo realno grožnjo skupnosti, se taka čustva hitro izostrijo in so obrambni mehanizem ter motivacijska platforma za njen obstoj. Žal pa domoljubje lahko hitro postane žrtev ločevanja skupnosti, kar je še posebno aktualno v času notranjih državnih in asimetričnih konfliktov. Pogoj za vodenje takega boja je oblikovanje čim bolj homogenizirane skupnosti, ki temelji na jasni drugačnosti, dodan pa ji je tudi šovinizem - jasno poniževanje drugih in poveličevanje svojih pripadnikov skupnosti. To pa je jasen korak prevrednotenja domoljubja v nacionalizem, ki vodi v oblikovanje posameznih zaključenih družbenih skupnosti kot celice vodenja oboroženega boja. Zato moramo domoljubje kot izoblikovano čustvo, na katerem temeljita narodna samozavest in s tem strpnost, razumeti kot porok za zmanjševanje možnosti sporov in večjo socialno kohezivnost v družbi kljub morebitnim razlikam v njej. Ta izhodišča pa so bistvena, saj je domoljubje najosnovnejši gradnik vsakega obrambnega sistema, zlasti takrat, ko govorimo o državni vojski, ki poleg vseh značilnosti kot najbolj državotvoren element pravzaprav definira državo. Če izhajamo iz tega, se morajo pripadniki oboroženih sil popolnoma identificirati z državo, ki naj bi jo branili in skrbeli za njene interese. To pomeni, da je vojaška služba najbolj izrazito državna služba in na njeno identiteto pomembno vpliva nacionalna identiteta (Južnič, 1993, str. 27-31), zato domoljubje ostaja, kar je od nekdaj bilo, in sicer temeljna vrednota vsakega vojaka. Kar mogoče lahko postane vprašljivo, je, ali lojalnost režimu oziroma vladajočim elitam prevlada $\mathrm{v}$ primerih nasprotno si stoječih vrednot v razmerju do lastnega naroda. Z drugimi besedami, ali vojaški sistem sledi političnim odločitvam tudi tedaj, ko te niso več domoljubne in ne predstavljajo blaginje za ves narod oziroma v skrajnosti lahko pomenijo zapostavljanje naroda zaradi lastnega preživetja.

\section{DOMOLJUBJE IN NACIONALNA IDENTITETA}

Vprašanje nacionalne identitete je danes kljub občutku, da je svet postal majhna globalna vas, še kako pomembno. To še posebej velja $\mathrm{v}$ globaliziranem in multikulturnem svetu, kjer se vse bolj jasno zarisuje os lokalno - nacionalno globalno (Pikalo, 2010). Pri tem gre seveda tako za pomen lastne osebne identitete kot tudi nacionalne. Kot ugotavljata Prebilič in Barle Lakota, je aktivno in samozavestno nastopanje v globalnem okolju mogoče samo, če imamo zelo trdno zasidrane korenine. Kar pa ni mogoče, če povsem zanemarimo vidik domoljubja kot osnove oblikovanja identitete (Prebilič in Barle Lakota, 2011, str. 176). 
Identiteta je sestavljena iz podobnosti in razlik, je način, po katerem se posamezniki ali skupnosti razlikujejo v primerjavi z drugimi posamezniki ali skupnostmi (Ule Nastran, 2000, str. 3). Ko govorimo o nacionalni identiteti, s katero so neposredno povezani vojaški sistemi, gre za vsoto dejavnikov, ki določajo nabor podobnosti in razlik. Je svojstvena, nezamenljiva in neodtujljiva. To je jedro naroda, njegovo bistvo in njegov smisel obstoja. Ker se je mogoče strinjati z dejstvom, da je večina narodov v svojem zgodovinskem razvoju le postala tudi nacija in tako oblikovala svojo ter $\mathrm{v}$ mednarodnem prostoru priznano državno tvorbo, je povsem logično razumeti vojaško identiteto v povezavi z nacionalno. Prav vojaški sistem je namreč branik obstoja naroda, nedvomno pa nacije, zato je vojaška identiteta v razmerju do nacionalne identitete posebna in ji je strukturno ter vsebinsko nekako podrejena. Nacionalno identiteto moramo razumeti kot izostreno in opredmeteno komponento sicer vsebinsko širše nacionalne zavesti, ki jo Južnič (1993, str. 320) razume kot najbolj bistven sestavni del nacionalne identitete. Ta se oblikuje skozi daljša zgodovinska obdobja in je nerazdružljivo povezana s prostorom ter nacijo tega prostora. Prav to pa je bistveno v vsej zasnovi identitete. Temeljna značilnost je poleg že omenjenih lastnosti zmožnost identificiranja tako posameznikov kot družbenih skupin. In prav s prostorsko sestavino se je najlažje poistovetiti in je posredno ter neposredno pomemben dejavnik vpliva na nacionalno identiteto. Po Smithu (1998) ima nacionalna identiteta dvojno funkcijo: ekonomsko-teritorialno-politično funkcionalnost, ki zagotavlja državi vire, ozemlje in delovno silo, naslanja pa se na racionalne procese, toda tudi zasebno notranjo funkcionalnost, ki posamezniku zagotavlja samodefiniranje, samospoštovanje ter zaznave sebe in drugih. Postavlja pa se vprašanje možnosti identifikacije in pripadnosti svoji etnični skupini ter hkrati delitev vrednot in občutkov identifikacije s širšo, heterogeno skupino (Sidanius in drugi, 1997).

Mogoče in morda nujno pa je predstaviti še eno, nič manj ali celo bolj pomembno tretjo funkcijo nacionalne identitete - varnostno. Res je, da je ta funkcija v veliko primerih posledica delovanja drugih sistemov, ne samo in izključno nacionalnovarnostnega, zlasti kadar je govora o varnosti v njenem najširšem pomenu besede, je pa to izrazito izostreno v primerih obrambe elementov nacionalne identitete. Varnost v najširšem pomenu besede lahko opredelimo kot stanje, v katerem je zagotovljen uravnotežen fizični, duhovni in duševni ter gmotni obstoj posameznika in družbene skupnosti v razmerju do drugih posameznikov, družbenih skupnosti in narave (Grizold, 1992, str. 63). Ali drugače: zgodovina nas uči, da popolna prisilna integracija, katere cilj je izkoreniniti narod ali nacijo, zahteva najprej vojaško premoč in nato sistematične ukrepe raznarodovanja oziroma izbrisa nacionalne identitete. In prav to je temeljni cilj vseh vojaških sistemov. Sistematični ukrepi raznarodovanja so vrhunec dosegli prav v času tik pred in med drugo svetovno vojno. Za to obdobje (glej Ferenc, 1996) je značilna najbolj brutalna oblika fizičnega izkoreninjenja tedaj vse bolj jasno izrisanih potez slovenske nacionalne identitete. Z vsemi sredstvi so želeli preprečiti vojaško nadvlado in neprekinjeno delovati pri zaščiti svojega naroda oziroma nacije. To pa vključuje tudi pojem nacionalne identitete. 


\section{DOMOLJUBJE IN NACIONALIZEM}

Domoljubje se pogosto pojavlja v istem kontekstu kot nacionalizem, vendar pa ju ne gre zamenjevati (glej tudi Nincic in Ramos, 2012). Najprej je nacionalizem povezan s konceptom nacije, torej konstitutivnega naroda, naroda, ki je dosegel oziroma si zagotovil državo. Zato je hote ali nehote povezan tudi z državnimi atributi in je s tega vidika nadpomenka domoljubju, ki se lahko in tudi se oblikuje v večnacionalni državi oziroma v državi, kjer prevladuje kak večinski, najmočnejši ali najvplivnejši narod. Razmerje med njima navadno ni komplementarno, temveč prihaja do trenj med njima. Obstaja pa tudi drugačna razlika med obema pomenoma. Domoljubje pomeni pozitivno čustveno razmerje do dežele, torej domovine in ljudi, ki ji pripadajo (Sruk, 1995, str. 234), ter ima največkrat naklonjen odnos do pripadnikov drugih narodov, kultur in ras. Za nacionalizem te prvinske pozitivne karakternosti ni mogoče vedno dokazovati. Nacionalizem ima namreč zelo različne politične in družbenomoralne implikacije in manifestacije: od skrajno pozitivnih do popolnoma nesprejemljivih, med katere spadajo vse tiste oblike, ki so prežete z nedemokratičnostjo, skrajnim nacionalnim šovinizmom, ekstremno ksenofobijo in superiorno ideologijo, ki temelji na poniževanju ali podjarmljenju drugih, navadno manjših narodov in nacij (Prebilič in drugi, 2013, str. 11).

Domoljubje v demokraciji odraža ljubezen, ki ljudi združuje in povzroči, da so posledično za nacionalno državo pripravljeni storiti marsikaj. Domoljubje najpogosteje definiramo kot predanost državi, nekateri avtorji pa tudi kot predanost narodu (Prebilič in drugi, 2013, str. 11). Nikakor pa domoljubja ne smemo in ne moremo enačiti $\mathrm{z}$ nacionalizmom, čeprav si vsaj $\mathrm{v}$ delu delita isto vrednostno izhodišče - narodi obstajajo, obstoj lastnega naroda pa ima za posameznika posebno moralno vrednost, zato je narod vreden posebne naklonjenosti. Vsak nacionalist je tako gotovo tudi domoljub, zavezan pripadnosti svoji domovini in svojemu narodu, vendar pa vsak domoljub ni nujno tudi nacionalist v smislu iskanja skladnosti naroda ${ }^{1}$ (Prebilič in drugi, 2013, str. 12).

Občutek pripadnosti državi (domoljubje) in naciji (rodoljubje ${ }^{2}$ ) navadno označujemo kot nacionalno identifikacijo. V lastni nacionalni državi se domoljubje in rodoljubje pokrivata. Pri državljanih, ki ne živijo v svoji nacionalni državi, pa se domoljubje in rodoljubje razlikujeta, na primer Slovenci v Sloveniji se identificirajo s slovensko državo (domoljubje) in s slovensko nacijo (rodoljubje), slovenski državljani drugih nacionalnosti pa se identificirajo samo po domoljubju s slovensko državo, ne pa tudi po rodoljubju s slovensko nacijo. Seveda je povsem mogoče, da se nekdo ne poistoveti tudi s svojo domovino. Pripadnost je torej lahko subjektivna in objektivna.

\footnotetext{
Ta je najprej povezan s konceptom nacije, torej konstitutivnega naroda, ki je dosegel oziroma si zagotovil državo. Zato je hote ali nehote povezan tudi z državnimi atributi in je s tega vidika nadpomenka domoljubju, $k i$ se lahko in tudi se vzpostavi v večnacionalni državi oziroma v tisti, v kateri prevladuje kak večinski, najmočnejšs ali najvplivnejši narod. Razmerje med njima navadno ni komplementarno, temveč se med njima pojavljajo trenja.

2 Rodoljubje je opredeljeno kot »čustvena povezanost z nacionalno skupnostjo« (Prebilič in drugi, 2013, str. 18).
} 
Če se državljan neke države ne identificira z državo, v kateri živi, se v tem primeru objektivna in subjektivna identifikacija ne pokrivata.

Nacionalizem se razlikuje od domoljubja, ker v nacionalno identifikacijo poleg domoljubja vključuje tudi rodoljubje. Domoljubje in rodoljubje sta res dve dimenziji nacionalne identifikacije, ki se merita z neodvisnimi skalami, vendar pa to ne pomeni, da je rodoljubje nujno agresivno in povezano s ksenofobijo ${ }^{3}$. Ksenofobija je druga spremenljivka, ki se razlikuje od domoljubja, je pa lahko v enaki meri povezana $\mathrm{z}$ domoljubjem in rodoljubjem. Seveda je mogoče, da dobi nacionalna identifikacija v nekaterih okoliščinah negativen predznak; v tem primeru se nacionalizem, ksenofobija in šovinizem pomensko zelo približajo.

Domoljubje in rodoljubje sta povezana s poznavanjem nacionalne skupnosti in države. To vedenje (znanje) ni dano, niti se ne podeduje, temveč moramo do njega priti z raziskovanjem in prenosom na mladi rod. Nacionalna zavest se razvija $\mathrm{s}$ pomočjo kulturnih vsebin in znanja o domovini. Prav tako ta zavest obstaja $\mathrm{v}$ objektivnem in subjektivnem smislu, ki se razlikujeta, saj noben posameznik ne more vedeti vsega o svojem narodu in domovini, zato mora biti določen neki minimum, ki naj bi ga poznali vsi posamezniki, da bi se lahko izoblikovala solidarnost med člani nacionalne in državne skupnosti. Nacionalizem ima veliko pomenov. Nekateri ga izenačujejo z domoljubjem in rodoljubjem in je predvsem politično načelo, ki naj zagotovi istovetnost politične in nacionalne skupnosti. Ob tem je Smith (2003) prepričan, da vdanost naciji nima tekmeca, zato je nacionalizem najvišja vrednota kolektivne avtonomije (Smith, 2003). Prav zato je treba razlikovati zaščito vrednot lastne kulture od negativnih občutkov do vrednot drugih kultur. Šovinizem je tak negativen občutek do pripadnikov drugih kultur. Nacionalizem je doktrina, po kateri se človeštvo deli na nacije, edina legitimna oblika vladavine pa je upravljanje samega sebe (Smith, 2003), zato smrt za domovino pomeni moralno vzvišenost, ki je ne morejo doseči smrti za druge pripadnosti (Benedict, 1990).

\section{DOMOLJUBJE IN NACIONALNA VARNOST}

Kot smo že ugotovili, je domoljubje najbolj osnoven gradnik vsakega obrambnega sistema. Zakaj? Več je vzrokov, velja pa izpostaviti dva, morda najbolj bistvena: obramba domovine pomeni zaščititi življenjski prostor naroda, kar je seveda pogoj za njegov obstoj in zaščita naroda. Seveda pa je še bistveno bolj preprost in vsakdanji vzrok: domoljubje pomeni ščititi dom, svoje najbližje, bistvo vsake družbe - družino. Če izhajamo iz tega, se morajo pripadniki oboroženih sil popolnoma identificirati z državo, ki naj bi jo branili in skrbeli za njene interese. Iz tega izhaja tudi antično poveličevanje smrti za domovino, o kateri je pisal v svojih Odah Horacij, in kar je bistveno sporočilo Homerja - Sladko in častno je umreti za svojo domovino (Lanning, 2005, str. 14). Bistvenih sprememb v tem pogledu domoljubja skozi optiko vojaške službe niti ni bilo. Celo več, vzpon najemništva v 15. in 16. stoletju je nujo

\footnotetext{
Z besedo ksenofobija označujemo sovraštvo do tujcev in vsega, kar je tuje. Gre za vrsto fobije, pri kateri se kaže pretiran strah pred tujci (Prebilič in drugi, 2013, str. 18).
} 
po tesnejši povezanosti med domoljubjem in oboroženimi silami ponovno postavil v ospredje, saj se je prav nedomoljubnost oziroma identitetna kriza najemnikov izkazala kot največja in ključna pomanjkljivost take vojske ${ }^{4}$. Zato ostaja in je bilo domoljubje vedno temeljna vrednota vsakega vojaka. Pri tem se poraja pomembno vprašanje povezanosti med domoljubjem in nacionalno varnostjo.

Prav zaradi teh dejstev je mogoče dokazati tesno in neposredno povezanost med nacionalno ter vojaško identiteto, ki čustveno in komplementarno dopolnjuje domoljubje.

Kot ugotavljata Prebilič in Juvan (2012), je mogoče trditi, da obstajajo nekateri elementi vojaške tradicije, ki ustvarjajo vsako vojsko in predstavljajo bistvo sistema. Med drugimi spada med te elemente tudi »jasno opredeljen patriotizem, ne kot sestavni del nacionalizma v negativnem pomenu besede, temveč kot ljubezen do domovine in naroda v obliki zaščitnika«. Ob že ugotovljenem ne smemo pozabiti na vsem znani Hungtingtonov model vojaške profesije, ki temelji na treh dimenzijah: (specialističnem) znanju, odgovornosti in bojni morali (l'esprit du corps) (Ilisoi in Nagy, 2004, str. 123). Če je prva stvar izobraževanja, urjenja in usposabljanja, sta drugi dve povezani z domoljubjem, saj se navezujeta na udejanjanje znanja, in s tem z delovanjem oboroženih sil. Pri tem pa nedvoumno trčimo na vprašanje: koga braniti in zakaj? Brez vsebinsko jasnega in razumljivega odgovora tretja dimenzija, ki se nanaša na bojno moralo, nedvomno ne bo dosegla svojega namena, s tem pa je v osnovi hendikepirana vojaška profesija in neposredno prizadeta bojna moč.

Verjetno ni naključje, da so največ raziskovalne pozornosti namenili odnosu med domoljubjem in nacionalno varnostjo v Združenih državah Amerike (ZDA) ${ }^{5}$ in v Izraelu (Arad in Alon, 2006). ZDA kot država, ki je v posebnem stanju v »vojni proti terorizmu« vse od napada na World Trade Center 11. septembra 2001, in druga, kot država, ki je zaradi zgodovinskih okoliščin v stanju vojne pripravljenosti vse od njene ustanovitve leta 1947. Na podlagi tega je mogoče domnevati, da mora biti država v stanju ogroženosti (resnični ali navidezni), da se začne zavedati pomena domoljubja kot temeljne sestavine nacionalne varnosti. Po drugi strani pa je vsekakor mogoče najti tudi take države, ki se ne spoprijemajo s stalnimi in neposrednimi grožnjami njihovi varnosti, pa so kljub temu znane po visoki stopnji domoljubja.

Bistvenega pomena za celotno razpravo o povezavi med domoljubjem in nacionalno varnostjo je, da zavrnemo povezave med domoljubjem, nasiljem in nagnjenostjo $\mathrm{k}$ vojni. Nedvomno je lahko nekdo domoljub, vendar nasprotuje vojni in konkretnim vojaškim posegom. Tako enačenje domoljubja in podpore vojni je prišlo do izraza $\mathrm{V}$ prvih letih po začetku ameriškega vojaškega posega v Iraku leta 2003. Za razumevanje ameriškega domoljubja $\mathrm{v}$ omenjenem obdobju je treba razumeti tudi ameriško

\footnotetext{
4ojalnost 》condottierijev« je bila zagotovljena izključno skozi odnos, definiran z zadostnim plačilom. Res je, da spopadi med takimi vojaškimi profesionalci niso bili krvavi in marsikatero mesto ni utrpelo uničenja, saj je bila v ozadju vedno tudi preračunljivost, vendar čustvene vezi žrtvovanja prav v tem času popolnoma izgubijo svoj pomen in smisel (Trease, 1971, str. 342).

5 Podobno ugotavljajo tudi Prebilič in drugi (2013).
} 
pojmovanje domoljubja. Domoljubje je v ZDA v bistvu »kulturna konstrukcija, ki se krepi skozi različne simbolne rituale, na primer izobešanje zastave in recitiranje prisege zvestobe« (Hamilton, 2012, str. 15). Za razumevanje tega koncepta je treba osvetliti tudi zgodovinski koncept in diahrono uporabo domoljubja. O'Leary in Platt (v Hamilton, 2012, str. 17) zagovarjata, da so bili rituali, povezani z domoljubjem, »institucionalizirani v času med državljansko vojno v 19. stoletju in med prvo svetovno vojno«. Rituali in simboli, ki jih danes jemljemo kot značilno ameriške, so $\mathrm{v}$ resnici posledica zavestne konstrukcije. Ljubezen do domovine in nacionalno pripadnost je treba gojiti in krepiti ter se ju naučiti. V času oblikovanja in razvijanja domoljubja v ZDA sta se izoblikovala dva izraza domoljubja: domoljubje kot ljubezen do domovine in domoljubje kot ljubezen do načela. Ljubezen do domovine se dotika vprašanja zvestobe: domovino je treba ljubiti in ji biti zvest ne glede na politike in ukrepanje. Ljubezen do načela pa se dotika vprašanja nacionalnih vrednot: domovino je treba ljubiti in ji biti zvest zaradi tega, kar predstavlja oziroma zagovarja (Hamilton, 2012: 17).

\subsection{MLADI, DOMOLJUBJE IN VOJSKA}

Vojska lahko deluje kot domoljubna struktura v tolikšni meri, kot so domoljubni njeni pripadniki. Vsekakor je za domoljubje pripadnikov določenih oboroženih sil bistveno tudi to, koliko so domoljubni mladi, iz katerih se »črpa« človeška sila za oborožene sile. Tako je za razpravo o vlogi SV kot domoljubne strukture treba raziskati tudi domoljubje med splošno slovensko populacijo mladih, ki v določenem deležu predstavljajo morebitne bodoče pripadnike SV.

Raziskava med slovensko populacijo mladih je bila izvedena na dveh ločenih vzorcih, in sicer $\mathrm{z}$ uporabo praktično enakega vprašalnika za vsako izmed obeh ciljnih (mladih) populacij. Časovno gledano sta bili obe raziskavi izvedeni hkrati, marca in aprila 2012, na reprezentativnem vzorcu 1000 učencev zadnjih razredov osnovnih šol in 1000 dijakov zadnjih letnikov srednjih šol; pri tem so bile v reprezentativni naključni vzorec enakopravno vključene osnovne in srednje šole iz vseh slovenskih pokrajin. Vprašalnik je bil s pomočjo anketarjev posredovan v 45 izbranih osnovnih šol iz vseh statističnih regij (reprezentativni vzorec) v Sloveniji, kjer je vprašalnik ob prisotnosti anketarjev izpolnilo 915 učencev zadnjih razredov (od 1000 posredovanih vprašalnikov, kar predstavlja 91,5-odstotno realizacijo). Hkrati je bil vprašalnik prek anketarjev posredovan tudi v 45 srednjih šol v vse slovenske regije (reprezentativni vzorec), kjer je vprašalnik ob prisotnosti anketarjev izpolnilo 964 dijakov zaključnih letnikov srednjih šol (od 1000 posredovanih vprašalnikov, kar predstavlja 96,4odstotno realizacijo). Podatki iz vrnjenih vprašalnikov so bili obdelani s pomočjo statističnega programa SPSS. Rezultati in analiza celotne raziskave so bili objavljeni v knjigi Odnos mladih do domoljubja, avtorjev Prebilič, Haček in Kukovič, ki je izšla leta 2013 pri založbi Fakultete za družbene vede v Ljubljani. Za našo razpravo bomo uporabili le tiste podatke, ki se nanašajo na odnos mladih do nacionalne varnosti in vojske, ter podatke, na podlagi katerih je mogoče sklepati o odnosu mladih do domoljubja. Za SV je bistveno vedeti, kakšna je populacija, ki vstopa v službo v SV. 
Učenci osnovnih šol so bili naprošeni, naj skladno s svojimi prioritetami razvrstijo svoje interese. Iz spodnje tabele (glej tabelo 1, prvi stolpec) je razvidno, da učenci osnovnih šol največji interes izkazujejo za prijateljstvo $(3,74)$, temu sledijo zabava in prosti čas $(3,69)$, služba in poklic $(3,53)$, spolnost in ljubezen $(3,38)$. Odgovori srednješolcev (glej tabela 1, drugi stolpec) so podobno razporejeni. Največji interes prav tako izkazujejo za prijateljstvo $(3,75)$, zabavo in prosti čas $(3,65)$, službo, poklic $(3,63)$ ter spolnost in ljubezen $(3,55)$.

\begin{tabular}{|c|c|c|}
\hline Interes & $\begin{array}{l}\text { Srednje vrednosti } \\
\text { odgovorov } \\
\text { (OSNOVNA ŠOLA) }\end{array}$ & $\begin{array}{c}\text { Srednje vrednosti } \\
\text { odgovorov } \\
\text { (SREDNJA ŠOLA) }\end{array}$ \\
\hline prijateljstvo & 3,74 & 3,75 \\
\hline zabava in prosti čas & 3,69 & 3,65 \\
\hline služba, poklic & 3,53 & 3,63 \\
\hline spolnost in ljubezen & 3,38 & 3,55 \\
\hline skrb za lastni zgled, zunanji videz & 3,35 & 3,24 \\
\hline šola in izobraževanje & 3,33 & 3,32 \\
\hline delo in zaposlitev & 3,32 & 3,53 \\
\hline družinsko življenje & 3,31 & 3,33 \\
\hline šport in športno dogajanje & 3,14 & 2,97 \\
\hline znanost in znanstveni dosežki & 2,54 & 2,57 \\
\hline tehnika in tehnični dosežki & 2,5 & 2,50 \\
\hline umetnost in kultura & 2,39 & 2,44 \\
\hline nastajanje neodvisne slovenske države & 2,37 & 2,36 \\
\hline nacionalna preteklost in usoda naroda & 2,35 & 2,37 \\
\hline vera in versko življenje & 2,15 & 1,94 \\
\hline vojska in vojaške zadeve & 2,12 & 1,94 \\
\hline politika in politična dogajanja & 1,89 & 2,02 \\
\hline
\end{tabular}

Pridobljeni podatki jasno izražajo range njihovega zanimanja, med katerimi izrazito zaostaja zanimanje za politiko in politična dogajanja. Prav nič bolje ni z zanimanjem za vojsko in vojaške zadeve, ki je pri srednješolcih celo na zadnjem mestu skupaj z vero in verskim življenjem $(1,94)$. To je zaskrbljujoče, saj je to področje zaradi večjega zanimanja za tehniko uživalo večjo podporo. Vzrok lahko najverjetneje pripišemo jasnejši ločitvi med civilnim in vojaškim okoljem, kar se je povsem očitno vzpostavilo tudi v mišljenju in zavedanju mladih in ne zgolj starejših. Drug vidik, morda še bolj zaskrbljujoč, pa je dejstvo, da je zelo nizko tudi zanimanje, povezano $\mathrm{z}$ nastankom neodvisne slovenske države $(2,37$ in 2,36$)$, nacionalno preteklostjo in usodo naroda $(2,35$ in 2,37$)$. Pri obeh skupinah odgovorov so vsi precej nizko izmed 
vseh sedemnajst interesov. Na podlagi tega je mogoče sklepati, da je zanimanje mladih za vojsko in vojaške zadeve skoraj nepopravljivo nizko na njihovi interesni lestvici. Z drugimi besedami, tako nizek interes kaže že popolnoma apatično držo mladih do vojske. Prav to pa je tudi predmet rahle kontroverznosti, ki jo tudi sicer vse bolj lahko spremljamo v sodobnih družbah - odrivanje vojaške institucije na obrobje civilne družbe ter hkratno zaupanje v njen profesionalizem. Mladi namreč ob procesu merjenja zaupanja v institucije prav Slovensko vojsko (tako osnovnošolci kot srednješolci) uvrščajo na sam vrh v Republiki Sloveniji (glej graf 3). SV je tako tista institucija, ki ji mladi najbolj zaupajo, vendar je zanimanje zanjo zelo majhno. Vzrok je poleg profesionalnosti vojske nedvomno tudi njena oddaljenosti od vsakdanjih dnevnopolitičnih dogajanj, v še vedno žlahtnem prepoznavanju vloge vojske pri obrambi domovine in v močnem humanitarnem poslanstvu, ki se izkazuje ob različnih naravnih nesrečah v Sloveniji. V sicer konfuznem in moralno načetem družbenem sistemu se zdi, da je vojska institucija, ki kljub vsemu ohranja del vrednostnega sistema, predvsem kot nekakšno obliko zanesljivosti in stabilnosti.

Graf 1:

3,5

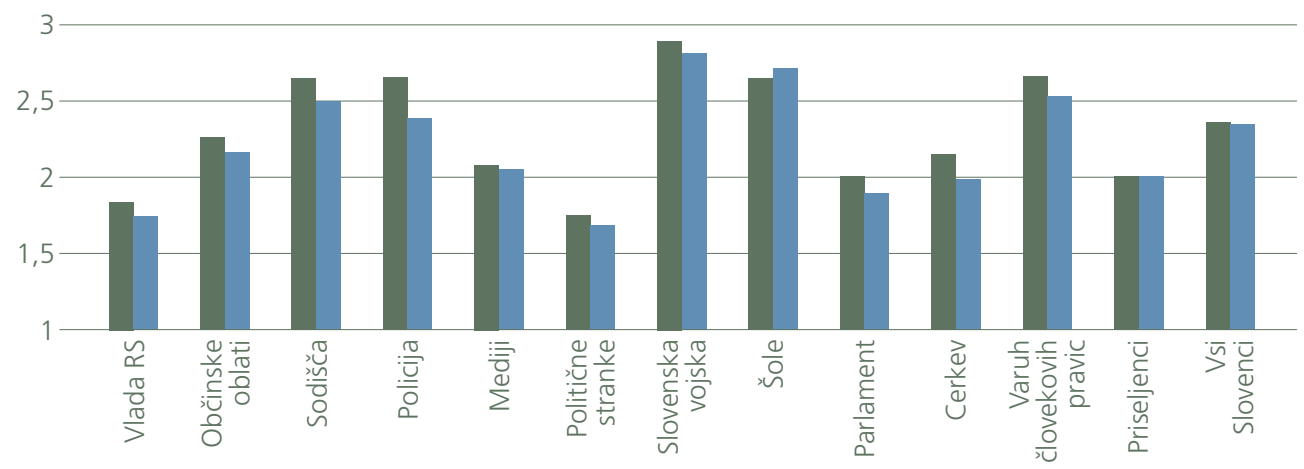

Osnovne šole

Srednje šole

In tu se kontroverznosti, povezane s SV in mladimi v Sloveniji, ne nehajo. Pri evalvaciji domoljubnih komponent in njihovi izraznosti so se izkazala zanimiva dejstva. Če je za vojsko spoštovanje državnih simbolov ne samo zakonsko opredeljeno dejstvo, temveč tudi izrazita notranjesistemska častna vrednota, ki je del vsake vojaške tradicije, tega med mladimi ni zaznati (glej graf 4). Razobešanje slovenske zastave zanje ni pomembno (vrednosti dosegajo $20 \%$ ), prav tako so manj pomembni poznavanje lastne zgodovine (manj kot $35 \%$ ) ter aktivnosti s področja narodne solidarnosti (vsega $30 \%$ ) in zaščita nacionalne kulturne in naravne dediščine (manj kot 30 \% vprašanih mladih). Posebej pa je komentarja vredno dejstvo, da 
mladi med domoljubne komponente ne prištevajo tudi obrambe domovine. To bi storilo vsega 27 \% srednješolcev in bistveno več osnovnošolcev - 57 \%. Vzrok za tako veliko razliko med mladimi v vsega štiriletnem razmiku lahko pojasnimo z že omenjenim razmišljanjem v sodobni družbi - obrambo domovine naj opravijo tisti, ki so zato plačani in usposobljeni, mladi za državo pač niso pripravljeni žrtvovati svojega življenja (kar je nedvomno tudi posledica nizke stopnje zavednosti pomena države in slabe lastne artikulacije domoljubja), kar se žal kaže v precejšnji razočaranosti nad državo, ki jo mladi ocenjujejo skozi politike, državne institucije in dnevnopolitično dogajanje. V tem pogledu SV seveda ni krivec. Pravzaprav je izjema, da kot pomemben institucionalni del države ohranja visoko in kakovostno samopodobo, nedvomno pa ta dejstva ne govorijo v prid državi kot celoti, saj je prav družbena kohezija pogoj za spopad z različnimi nacionalnimi (pre)obremenitvami in je zanje potreben določen družbeni konsenz.

Graf 2: Zelo pomembno se mi zdi, da domoljuben državljan ...

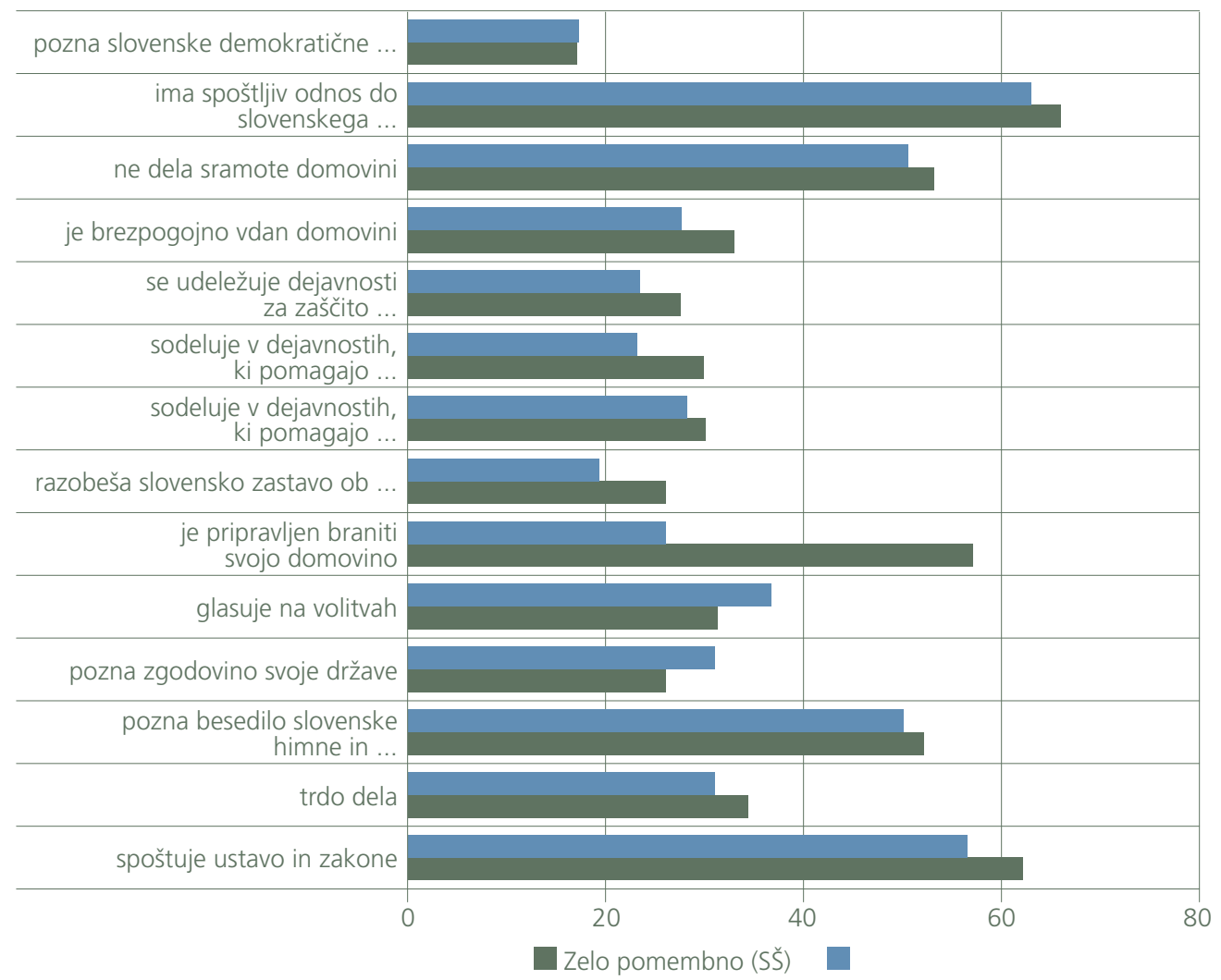


Sklep Ko govorimo o domoljubju, mladih in nacionalni varnosti, je mogoče ugotoviti, da med temi subjekti nedvomno je neka povezanost, ki bi morala vsaj v določenih dejstvih biti popolnoma jasna, nedvoumna in bi se morala medsebojno dopolnjevati. Pravzaprav bi lahko sklenili, da naj bi mlada, zdravo domoljubna oseba morala biti tista, ki ji varnost in obramba domovine veliko pomenita. Pa ni povsem tako. Najprej ta mlada domoljubna oseba ni družbeno aktivna, kar pomeni, da je distancirana od tega, kaj in kako se z njeno domovino dogaja. Taka ni aktiven član skupnosti, temveč izrazito pasiven, ki v številnih primerih popolnoma ignorira življenje okoli sebe. Razrast takega razmišljanja pa nedvomno pomeni konec našega družbenega sistemademokracije. Ta zahteva sodelovanje pripadnikov neke skupnosti. Če te ni, to ni več vladavina večine, kakor jo sicer preprosto definiramo, temveč vladavina manjšine, ki pa se je v zgodovini že izkazala kot neuspešna oblika urejanja družbenopolitičnega življenja v posameznih skupnostih. Tukaj je še nacionalnovarnostna komponenta. Že besedna zveza nacionalna varnost jasno ugotavlja, da je za tako obliko varnosti treba zagotoviti koordinacijo prizadevanj nacije, torej vseh pripadnikov neke družbene skupnosti. Neaktivnost, družbeno nesodelovanje, apatičnost in individualnost so ne le jasni pokazatelji razpada družbene kohezije, temveč tudi prva ovira družbe v njenem razvoju. Samo tesno socialno kohezivne družbe so tudi uspešne, saj temeljijo na medsebojni pomoči, razumevanju in prerazporejanju nacionalnega bogastva na eni ter bremena na drugi strani med vse pripadnike te skupnosti. Z varnostjo ni nič drugače, z domoljubjem prav tako ne. Prav domoljubne družbe poleg spoštovanja kulture, jezika, zgodovine in izročila temeljijo najprej na spoštovanju njenih lastnih pripadnikov. Taka samopodoba pa je temelj za obrambo pred anomalijami družbe, kot je ekstremni nacionalizem in $\mathrm{z}$ njim povezana šovinizem ter ksenofobija. Neodgovorjeno vprašanje pa kljub temu ostaja: kdo in kako bo (če bo) kaj spremenil med našimi mladimi na dokazanih dejstvih v tem prispevku? Nekaj je namreč jasno samo se ne bo spremenilo nič!

1. Arad, U. in Alon, G., 2006. Patriotism and Israel's National Security. Institute for Policy and Strategy, Izrael. Dostopno na: http://www.herzliyaconference.org/eng/_ uploads/1388pat_e.pdf. 15. 3. 2013.

2. Benedict, A., 1990. Nacija: Zamišljena zajednica. Zagreb: Školska knjiga.

3. Conover, P. in Feldman, S., 1987. Memo to NES Board of Overseers Regarding "Measuring Patriotism and Nationalism. Dostopno na: http://www.electionstudies.org/ resources/papers/documents/nes002263.pdf. 20. 6. 2013.

4. Ferenc, T., 1996. Raznarodovalna politika okupatorjev. VEnciklopedija Slovenije. Zv. 10: Pt-Savn, str. 113.

5. Grizold, A., 1992. Oblikovanje slovenske nacionalne varnosti, V Grizold, A. (ur.), Razpotja nacionalne varnosti, Fakulteta za družbene vede, Univerza v Ljubljani.

6. Hamilton, H., 2012. Can You Be Patriotic and Oppose the War? V Controversia, Vol. 8 (1). Str. 13-35.

7. Južnič, S., 1993. Identiteta. Ljubljana: Fakulteta za družbene vede.

8. Ilisoi, D. in Nagy, D., 2004. Patriotism and Military Values, Management and SocioHumanities, "Henri Coanda" Air Force Academy, Brasov Romania, str. 121-25. 
9. Kahne, J. in Middaugh, E., 2006. Is Patriotism Good for Democracy? A Study of High School Seniors' Patriotic Commitments, Patriotism and Education, Phi Delta Kappan, Vol. 87, No. 8, str. 600-7.

10. Kosterman, R. in Feshbach, S., 1989. Toward a Measure of Patriotic and Nationalistic Attitudes. V Political Psychology 10 (2), str. 257-74.

11. Nincic, M. in Ramos, J. M., 2012. The Sources of Patriotism: Survey and Experimental Evidence. Foreign Policy Analysis, str. 373-88.

12. Lanning, M. L., 2005. Mercenaries, Balantine Books, New York, str. 42-52.

13. Parker, C. S., 2003. Shades of Patriotism: Group Identity, National Identity, and Democracy, Paper prepared for the annual meeting of the American Political Science Association in Pennsylvania. Dostopno na: http://www.polsci.ucsb.edu/faculty/parker/ workingpapers/shades_of_patriotism.pdf. 20. 3. 2013.

14. Pikalo, J., 2010. Državljanstvo in globalizacija, K državljanski vzgoji za sodoben svet, Ljubljana: Založba Sophia.

15. Prebilič, V. in Barle Lakota, A. 2011. Domoljubje v slovenskem šolskem sistemu. V Šolsko polje, letnik XXII, št. 1-2, str. 175.

16. Prebilič, V. in Juvan, J. 2012. (Ne)obstoj slovenske vojaške identitete $=($ Non)existence of Slovenian military identity. Sodobni vojaški izzivi, letn. 14, št. 1, str. 55-67.

17. Prebilič, V., Haček, M., in Kukovič, S. 2013. Odnos mladih do domoljubja, Ljubljana: FDV.

18. Schatz, T. R. in Stauc, E., 1997. Manifestations of Blind and Constructive Patriotism: Personality Correlates and Individual-Group Relations. VD. Bar-Tel, Staub, E. (ur.), Patriotism in the Lives of Individuals and Nations, Chicago, Nelson Hall, str. 229-245.

19. Sidanius, J., Feshbach, S., Levin, S., in Pratto, F. (1997): The Interface Between Ethnic and National Attachment - Ethnic Pluralism or Ethnic Dominance? Public Opinion Quarterly, 61, str. 102-133.

20. Smith, A. D., 1998. Nacionalni identitet. Beograd: Čigoja štampa.

21. Smith, A. D., 2003. Nacionalizam i modernizam. Zagreb: FPZ.

22. Sruk, V., 1995. Leksikon politike. Maribor: Založba Obzorja.

23. Trease, G., 1971. The Condottieri-Soldiers of Fortune, Holt, Reinhart and Winston Inc., New York.

24. Ule Nastran, M., 2000. Sodobne identitete v vrtincu diskurzov. Ljubljana: Zbirka Sophia. 